\title{
The location choice of graduate entrepreneurs in the United Kingdom
}

\begin{abstract}
The graduates' startup formation process represents a possible future role for universities in the form of active-participation , when speaking of the regional development. Tracking the path of entrepreneurial graduates who are moving between home, university, and employment, allows us to identify the specific motives that determine their migration decisions. The choice of location of graduate entrepreneurs is naturally affected by the context of their home region, as the availability of resources leads to a rising entrepreneurial intention. Similarly, the location of the startups flourish in densely populated urban regions, as well as in wealthier locations. At the same time, the vibrancy of the local entrepreneurial ecosystems is enhanced through mutual exchange and collaboration; and the higher the number of startups already present in a region, the higher the probability becomes for interaction and creativity. A leading tendency, not least to be mentioned, is that the preference to start new businesses is connected to highly-skilled creative sectors of the economy.
\end{abstract}

Keywords

graduate $\cdot$ region $\cdot$ startup $\cdot$ United Kingdom $\cdot$ university

(C) University of Warsaw - Faculty of Geography and Regional Studies

Introduction

Studying the spatial perspective of the formation of new firms is closely tied to research within the frame of regional innovativeness and economic development (see Bosma 2011; Cooke et al. 2011). Similarly, a strong connection between competitiveness of regions and the location of new firms is notable in recent research; for example: Fritsch \& Mueller 2007; Shane \& Venkataraman 2000; Buenstorf \& Klepper 2010. The authors clearly aim to introduce those factors that enhance a locality's attractiveness for new firms. Regions, in human geographic, understanding appear to exist through a specific set of characteristics that naturally embrace certain activities, and that are influential for regional growth and development process. These indicators should, according to the New Growth Theory ('triple helix', 'regional innovation systems', etc.), act as a reflection of the ability of a locality's environment to transform innovations, which have emerged from human and social capital, into new economic assets.

Thus, the creation of both new, small and medium enterprises (SMEs), and new industries, are connected with the vital force of the local environment and its potential to develop in a competitive way. However, the influential conditions of such a process are too complex to grasp easily. Some of these contextual factors are specific: new entrepreneurship as a family phenomenon, embeddedness in social ties, professional or organizational networks, the availability of finance. Some are more general: urbanization and population structures, the openness of the local culture, or the local knowledge base and production.

In this context, universities, as the actual producers and distributors of human capital are interesting to investigate. We aim to link the transforming role of these higher education $(\mathrm{HE})$
Eva Polonyová', Slavomír Ondoš ${ }^{2}$

Philip Ely ${ }^{3}$

'Department of Human Geography and Demography, Faculty of Natural Sciences, Comenius University in Bratislava; Slovakia e-mail: polonyova@fns.uniba.sk

2Department of Human Geography and Demography, Faculty of Natural Sciences, Comenius University in Bratislava; Slovakia e-mail: ondos@fns.uniba.sk

${ }^{3}$ Purple Door Student Enterprise at the Department of Employability, University of

Portsmouth; United Kingdom e-mail: philip.ely@port.ac.uk

Received: 19 March 2015

Accepted: 6 November 2015 institutions with the newly formed businesses and the location trends of those individuals that are being, or have been educated by them. These university-bred, creative individuals tend to remain in those locations that are supportive in directing their innovative activities towards a tangible economic benefit. But is the mere presence of the university functioning as the main factor in the retention of new entrepreneurs? This paper depicts the spatial distribution mechanisms of new graduate start-ups in the United Kingdom (UK). Utilizing the dataset of HE leavers, we uncover the basic models of reasoning that stand behind regional variations in new entrepreneurial activity.

A large share of recent studies, and not only within the stream of new economic geography, closely associates new and competitive entrepreneurship with knowledge (Giarratana 2004; Vincett 2010; Wright et al. 2012; Bishop 2012; Guerini et al., 2012; Baltzopoulos \& Broström 2013; Fritsch \& Aamouke 2013; Colombelli et al. 2013; Qian et al. 2013). Most of the recent approaches that have focused on the examination of university based entrepreneurship have emerged from the 'knowledge spillover theory of entrepreneurship' primarily introduced by Audretsch (1995), which places the new entrepreneurship within an endogenously created, academic knowledge utilization. These assets can lead an individual to the identification of new business opportunities (Acs et al. 2013; Audretsch et al. 2005) and venture creation.

According to Qian et al. (2013) this theoretical concept, referred to by Varga (2000) and Anselin et al. (2000) as the 'Griliches-Jaffe knowledge production framework', is grounded within the early work of Arrow (1962), Grilliches (1979), Jaffe (1989) and Romer (1990). These authors had already referred to knowledge and the high 
level of human capital quality as the key sources of newly emerging entrepreneurial activity.

Place, economy and the higher education

The studies, based on the knowledge spillover theory of entrepreneurship, generally regard knowledge as spatially bounded and thus, to a certain level, limited by shifting borders (Jaffe et al. 1993; Anselin et al. 1997; Acs et al. 2002; all in Qian et al. 2013). Most of these empirical approaches work with the notion of 'cognitive distance', aiming to explain the clusters of new firms based on interconnections with locally present academic environments. Developing an econometric model, these studies focus on researching the spatial range of such impacts.

Knowledge in this context takes on a codified form of inventions. These are born as an outcome of the scientific research activity of academics (Van Burg et al. 2008) and afterwards transferred through individuals to the newly-created entrepreneurs (Colombo et al 2010). Studies utilizing this approach, aiming to trace the process of learning through knowledge flows, rely mostly on the number of patent citations (Acs \& Sanders 2012; Guerini et al. 2012; Colombelli et al. 2013; Heblich \& Slavtchev 2013; Autant-Bernard et al. 2013), or the number of academic publications (Audretsch et al. 2005). The outcome is usually focused on defining the limiting barriers for interregional spillovers (Fritsch et al. 2013) by spatial distance thresholds (Woodward et al. 2006; Van Burg et al. 2008; Acs et al. 2009; Guerini et al. 2012), and patterns of the locations of university spin-off firms (Egeln et al. 2004; Heblich \& Slavtchev 2013).

Moving towards the individual person (an academia-based entrepreneur), a number of approaches can be naturally distinguished. Rothaermel et al. (2007) focused on the psychology of actually deciding to become an entrepreneur; Goethner et al. (2012) on one's own inner and professional transformation process, on levels of behaviour, motivation and intentions; D'Este et al. (2012) on specific skills and the capacity of the academic in contributing to an advance in competitiveness; and Landry et al. (2006) on analysing the level of their business-related success.

On the other hand, there is movement to adopt an opposite view, which uncovers the 'ivory-tower like' perception of academics who start new firms (Harrison \& Leitch 2005; Åstebro et al. 2012). Their evidence, in this context, mainly shows that alumni entrepreneurs, in reality, actually outnumber entrepreneurial academics from their parent university by a remarkable level.

\section{The graduate entrepreneur}

In fact, the newly created businesses represent the realworld reflections of the highly educated and creative individuals taking action within certain localities. Graduates are embodying the knowledge and skills they have acquired throughout their university studies and are carrying them across space and time. These individual actions can bring about an opportunity for truly influencing the growth of their final destination. Besides only a few recent acknowledgements (for example, by Lawton Smith et al. 2014, or Anderson et al. 2014), among the recent studies that deal with the knowledge spillover theory of entrepreneurship, a general lack of focus concerning startup alumni is obvious. However, a relatively large stream of research has been dedicated to this topic within the Polish literature on $\mathrm{HE}$, as recently exemplified by Piróg (2014a, 2014b) who has pointed out the value of entrepreneurial competencies among job-seeking graduate geographers; and Brzozowska et al. (2014) who reflected on the role of universities in awakening entrepreneurial attitudes.

Speaking of new entrepreneurship creation, Hsu et al. (2007) emphasized the importance of local human capital stock, together with entrepreneurial environment and suggested raising the real-life use of university knowledge in entrepreneurship.
Their evidence reports a significant and observable decrease in the time lag between graduation and first startup. Such an idea of time lag was more recently addressed by Müller (2010). These results argue that a lack of experience, support and resources are the most common factors in preventing graduates from starting up directly after graduation. The importance of focusing the design of educational programs and other supportive mechanisms on producing entrepreneurial graduates was depicted in the following years (Åstebro et al. 2012):again, emphasizing the high number of startups created by university graduates. A year later, a discussion on the position of a successful future university took place. The set of recommendations, of course, did not omit the development of the graduates' entrepreneurial skills as a crucial factor in the future competitiveness of their HE mother institution (Gibb et al. 2013).

Yet, only little is known about the actual mechanisms that could help universities generate and enhance higher rates of new entrepreneurship among their graduates. The more new businesses are created, the more able they are to promote local economic growth. However, spatial mobility among young skilled labour tends to be extremely high. These often very sudden migration flows then raise questions concerning the ability of localities to retain this young talent, educated by the local university.

A labour-market-placement focused analysis mapping the UK territory, has so far been the usual approach to this issue. The earliest research contributed by reporting the ranking of successful placements within the job market (Taylor 1986; Johnes et al. 1987; in Johnes \& Taylor 1989). More recent studies have clarified the connection between the migration to industrial clustering and innovativeness (Faggian \& McCann 2006, 2008, and 2009). And most recently, presenting the recruitment of graduates for regionally defined labour markets (Hoare \& Corver 2010), identifying a system of regional 'winners' and 'losers' as a result.

However, starting up as a graduate is different as it requires many more questions to be taken into account. These factors often become very personalized. Close personal bonds and ties are often pointed out as being crucial and essential for the creation of new firms (Audretsch \& Vivarelli 1996; Davidsson \& Honig 2003; Michelacci \& Silva 2007; Dahl \& Sorenson 2009 and 2010; Audretsch et al. 2011; Danis et al. 2011). The social capital accumulated during university studies simply offers an enhanced availability of sources (Broström 2013). Another study by Baltzopoulos and Broström (2013) reports on the so-called 'alumni effect', an 'embeddedness' of young entrepreneurs, arguing that almost half of new entrepreneurs, previously studying away from home, will set up their business within the region of their university studies.

\section{Choice of location}

Besides personal tendencies and attitudes, other objective aspects seem to affect the process of choosing a locality (Fritsch \& Mueller 2007). Attempting to explain the spatial pattern of density, the research either: compares the situation of the firm-formation process on a national level (Mueller et al. 2002; Mueller \& Thomas 2001; Bosma et al. 2008); depicts regional units (Carlton 1983; Ashcroft et al. 1991; Audretsch \& Fritsch 1994; Armington \& Acs 2002; Sutaria \& Hicks 2004; Plotnikova et al. 2010; Dawson et al. 2012); presents a specific location (Ashcroft et al. 1991; Brixy \& Niese 2003); or defines a unique industry (Giarratana 2004; Buenstorf \& Klepper 2010; Lasch et al. 2011). Systematizing the factors concerning the rationale behind the process of choosing a location by fresh entrepreneurs, we can identify six groups that overlap and supplement each other:

- The factor of relational networks. Social contacts, often informal, by definition evolve into social capital, once they contribute to fulfilling the entrepreneurial goals (Burt 1992, 
in Greve \& Staff 2003). These ties, built on mutual trust and face-to-face interaction, strongly frame the location of entrepreneurial startups, as well as their creation (Wagner \& Sternberg 2004; Audretsch et al. 2011; Soetanto \& Van Geenhuizen 2010). New entrepreneurs are strongly motivated to remain close to family and friends (Dahl \& Sorenson 2009 and 2010). The value of such capital ranks much higher than specific regional characteristics, especially for new businesses emerging within developed economies (Danis et al. 2011).

- The existing entrepreneurial atmosphere. A startup friendly environment can be understood through various attributes (political dimension, business tradition and performance, role models, etc.). Forecasting the potential for locating new firms, these influences were identified as key, mainly by: Mueller et al. (2002), Giarratana (2004), and Fritsch \& Mueller (2007).

- $\quad$ Strong local knowledge base. An impressive strand of empirical evidence uncovers the importance of available knowledge stock (Aldridge \& Audtresch 2011 are an example). In the process of shaping an entrepreneurial ecosystem, the influence of universities appears to be substantial. Authors often address cognitive proximity, and what is more, they refer to a particular type of necessary knowledge (Colombelli et al. 2013; Malecki 1997). The most recent view identifies knowledge as a major source of entrepreneurial opportunities, and human capital as a major source of absorptive capacity (Qian et al. 2013).

- Innovations. Emphasis of the focus placed on the inventions' creation process. Generating knowledge through innovation (Giarratana 2004; Lee et al. 2013; Van Geenhuizen \& Soetanto 2012) is again connected to academic, as well as R\&D stakeholders. Specific linkages between universities and industries are identified and new, knowledge-intensive firms are born as a result of technology transfer (Guerini et al. 2012; Qian et al. 2013; O'Shea et al. 2008).

- The socio-economic conditions. Early studies by Carlton (1983), Storey (1991), and Audretsch \& Vivarelli (1996) are only a few of those arguing that the labour market stability, or the existing concentrations of financial well-being, are key elements in the location of new entrepreneurships. In more recent studies the likelihood of choosing self-employment is linked to growing unemployment rates and to living in densely populated regions (Brixy \& Niese 2003; Wagner \& Sternberg 2004; Pickernell et al. 2011).

- Urban environment. Given a favourable combination of specific indicators, a city in itself offers an attractive environment for new entrepreneurs. The ability to pull in, and retain, creative and skilled individuals can be enhanced either through the presence of an HE institution and its research activity (Lawton Smith et al. 2014); or a generally more entrepreneurship-friendly climate. Cities mean a higher probability of personal interactions happening (Jacobs 1969). In addition, the most evident impact of local universities appears to take place in urban regions (Qian et al. 2013).

- On a national level, the context of cultural situations and social norms through various investigation of dimensions was performed within those studies, focusing on EU countries in an international comparison (Glinka et al. 2013). This factor and its context has been focused on; namely, through the Global Entrepreneurship Monitor survey results (Wach 2015).

Besides the theoretical dimension of these issues, there is a practical implication present. Being an active institutional agent, willing to modify local economic performance through attracting new businesses, university graduates appear to be a promising target group.

\section{Methods and data}

The specification of our model is built along the gravity framework, assuming the existence of a relationship between the observed startup numbers and the mobility of each startup founder. The model is specified in two versions according to the type of location choice: first for domicile (home) to university, and the second for university to employment (startup). A set of region-specific conditions influence behaviour in the home region and in the region of the startup location. The following factors are included: population density, unemployment rate, entrepreneurial activity of the population, startup rate in the regional economy, and the share of the sectors effect on the region's entrepreneurial activity. Scale variables measure the local resident population, and the student population of each region. Through this set of specifications, we have attempted to summarize the basic dimensions of a two-stage choice. With respect to the recommendations of Hoare \& Corver (2010), using twelve regions, we avoid the risk of commuting bias. The sectoral dimension is represented by 21 sections within the UK Standard Industrial Classification of Economic Activities (2007).

Count nature of the dependent variable leads us to start the estimation procedure with the Poisson regression. Equidispersion of the Poisson distribution assumes that mean equals variance. Because the assumption is violated in presence of overdispersion, the Poisson regression can be generalized for such cases into a negative binomial (NB) regression, or zeroinflated negative binomial regression (ZINB). The binary and the frequency generating process are treated separately. We use the same set of explanatory variables at both stages. Theoretical justification for the two stages is in first rejecting unacceptable options (consideration), and then maximizing the varying utility among the rest of the options (choice). This is the basis of so called two-stage choice models, which appear in various forms such as: consumer choice theory, tourism (Seddighi \& Theocharous 2002), hierarchical decision-making in labour migration (Fotheringham 1986), and other fields of study.

The primary source for data mapping the situation in the UK has been systematically collected and published by the Higher Education Statistics Agency (HESA). Destinations of leavers survey (DLHE), being an extensive data structure, was restricted by request to self-employed and freelance graduates, in other words, those starting up new businesses located in the UK. DLHE collects information from graduates from the UK's HE institutions, by asking them to fill in a questionnaire. Their target population consists of all students recorded for the time period beginning with August $1^{\text {st }}, 2011$ and ending July $31^{\text {st }}$, 2012, who are defined as individuals obtaining relevant higher education qualifications through full-time or part-time study (HESA 2013).

The total restricted population consists of 16,454 leavers, of which 718 reported an unknown outward postcode for their domicile. These persons are left out of the sample. An additional 39 leavers reported their domicile postcode as being external to the specified regional system of NUTS 1 regions (Guernsey, Jersey, and the Isle of Man). Another reason for excluding an individual leaver from the final sample is when reporting an unknown employment sector for the new firm (588). Since we assume the primary focus of another group of startups not linked with the UK local markets as highly probable, we applied the same exclusion-rule for four more individual leavers, as they refer to extraterritorial organisations as their main sector of activity.

Similar to previous cases of missing data, some leavers give incomplete information about location. In this case we decided to redistribute them according to the mid-2012 population, supposedly a more appropriate solution than further sample reduction, which would other wise reduce the number of English 
locations by 781 leavers, Welsh by 11 , Scottish by 37 , and Northern Irish by 11 and a further 178 indicating only 'UK'. Many startups have an unclear spatial focus at the beginning of their operation, particularly given the virtual nature of today's digital economy. A further 24 leavers reported startup locations external to the NUTS 1 regions (Guernsey, Jersey, and the Isle of Man). Reduction and redistribution finally resulted in a minor reduction of the sample to 15,119 persons, which covers $91.9 \%$ of the original restricted population.

Putting the sample into a wider employment activity context, the graduate entrepreneurs comprised $4.0 \%$ of the 411,000 leavers surveyed in 2011/12. The majority of them work fulltime $(54.7 \%)$, or part-time $(12.7 \%)$. Further study-related activity is reported by $13.6 \%$, combined with work $(7.3 \%)$, and the remaining 30,000 persons are unemployed $(7.3 \%)$ according to HESA (2013).

Secondary data used for the construction of explanatory variables are combined in a collection extracted from multiple resources. Startups and active businesses in regional economies are included in business demography statistics (ONS 2013). Regional student stocks are part of the annual overview of students in HE institutions (HESA 2013). Regional population is extracted from the mid-year estimates (ONS 2013). Geographical distances are derived from the data layer by EuroGeographics (2013). Regional unemployment is extracted from the Nomis database (ONS 2013). The dataset was finally completed by using additional observations covering the territory of Northern Ireland (NISRA 2013).

\section{Results}

The regional structure of the UK is generalized into five regional units combining NUTS 1: London (1), Other England (9), Wales (1), Scotland (1), and Northern Ireland (1). Table 1 reviews the relative weights for different parts of the country for estimated resident populations, and allocates the graduates according to their domicile. The asymmetry holds for all stages of the graduate's reported HE path. Concerning entrepreneurial career, it was found that London generates $37 \%$ more graduates than London graduates in general, hosts $61 \%$ more at local education institutions, and attracts $31 \%$ more self-employment compared to the labour market in general. The most balanced position is found in Other England. The imbalance then increases towards the negative for Wales (11-13\% less entrepreneurial graduates), Scotland (26-33\% less entrepreneurial graduates) and Northern Ireland (49-54\% less entrepreneurial graduates). These parts of the UK also apparently represent very different regional contexts in terms of conditions for creating and supporting the entrepreneurial career choice of the graduate.

The row standardized Table 2 represents the choice behaviour of respondents as observed from the base location of their domicile and their HE institution. The mobility network is illustrated graphically in the Figure 1. A graduate coming from a London-based household has an $82.6 \%$ probability of starting an employment career in London, but if deciding on self-employment, the probability of staying rises to $84.4 \%$. However, based on London's universities, graduates tend to start working in London less frequently $(71.7 \%)$. Even less frequent is their choice of staying in the location of study and starting new businesses $(69.8 \%)$. We found that graduates originating in Wales and Northern Ireland chose their home region even less for starting in a general employment career. But, this is not the case for graduates originating in Scotland. However, studies at Northern Ireland's universities seem to retain graduates in the region much more successfully than universities in Wales.
Table 1. Regional units and their share of total resident population and of leavers' population for home, university, and employment locations.

\begin{tabular}{|c|c|c|c|c|}
\hline & Population & Home & University & $\begin{array}{c}\text { Startup } \\
\text { (Employment) }\end{array}$ \\
\hline London & 13.0 & $\begin{array}{c}18.6 \\
(13.6)\end{array}$ & $21.9(13.6)$ & $26.4(20.1)$ \\
\hline $\begin{array}{c}\text { Other } \\
\text { England }\end{array}$ & 70.9 & $\begin{array}{c}69.8 \\
(70.3)\end{array}$ & $66.9(70.6)$ & $62.7(65.0)$ \\
\hline Wales & 4.8 & $\begin{array}{c}4.5 \\
(5.0)\end{array}$ & $4.8(5.5)$ & $4.0(4.6)$ \\
\hline Scotland & 8.3 & $\begin{array}{c}5.4 \\
(7.6)\end{array}$ & $5.3(7.8)$ & $5.5(7.5)$ \\
\hline $\begin{array}{c}\text { Northern } \\
\text { Ireland }\end{array}$ & 2.9 & $\begin{array}{c}1.7 \\
(3.5)\end{array}$ & $1.2(2.5)$ & $1.4(2.8)$ \\
\hline
\end{tabular}

Note: All respondents are in brackets. Source: HESA (2013).

The UK's migration flow system appears to be dominated by the linkages with England and London. The dominating preference can also be seen in the Table 3. The choice between the home region and a different region for one's university studies, is in relatively equal proportion, slightly advantaging studying at home. The second choice, made after graduation, reveals a much different and more unbalanced pattern. For those who move out of their university's region, there is a large bias for returning to their own location. The path probability taken by an entrepreneurial graduate shows that a combination of staying in the home region, leaving it for studies, and then returning is taken by 7 out of 10 graduates who report a startup career. The path that combines changing a region twice for new locations is taken by 1 out of 10 , which is the same as the path involving staying nearby university after considering the second choice.

The Table 4 answers the question: Which regional context represents an encouraging or discouraging context for an entrepreneurial graduate? The first model option is the Poisson model, which provides the parameter estimates that are driving the flows between regions. The dependent variable exhibits clear signs of overdispersion. The average flow is represented by five startups, with a standard deviation of 19 startups. Overdispersion is partially generated by 1,454 zero observations, $50.5 \%$ of the total sample.

Generalizations on the Poisson model can be found in following columns. The ZINB alternatively predicts firstly the distribution of zero observations in a binomial model ('Inflate'), and secondly predicts the values for non-zero observations using the NB model ('Count'). The Vuong test, which compares the ZINB model specification to the NB model, suggests that we truly observe a decision-making process in two stages: a rejection of certain options, followed by a carefully balancing positive and negative consequences of the choice between alternatives left after successfully passing the first stage.

Each flow is expected to be positively linked to the scale of origin, and destination; and negatively linked with the separation variable. A significant and correctly oriented effect is found everywhere with the exception of the flow origin in the first stage. The future graduate entrepreneurs are not willing to move to too distant a region when deciding on the location of university studies. What is more, they also prefer studying in regions with relatively large student populations. Table 4 reveals the importance of startup activity in the home region's economy. Experience with relatively frequent business startups leads to a more likely entrepreneurial path, as a single, significant home region effect. Significantly graduate entrepreneurs come more 


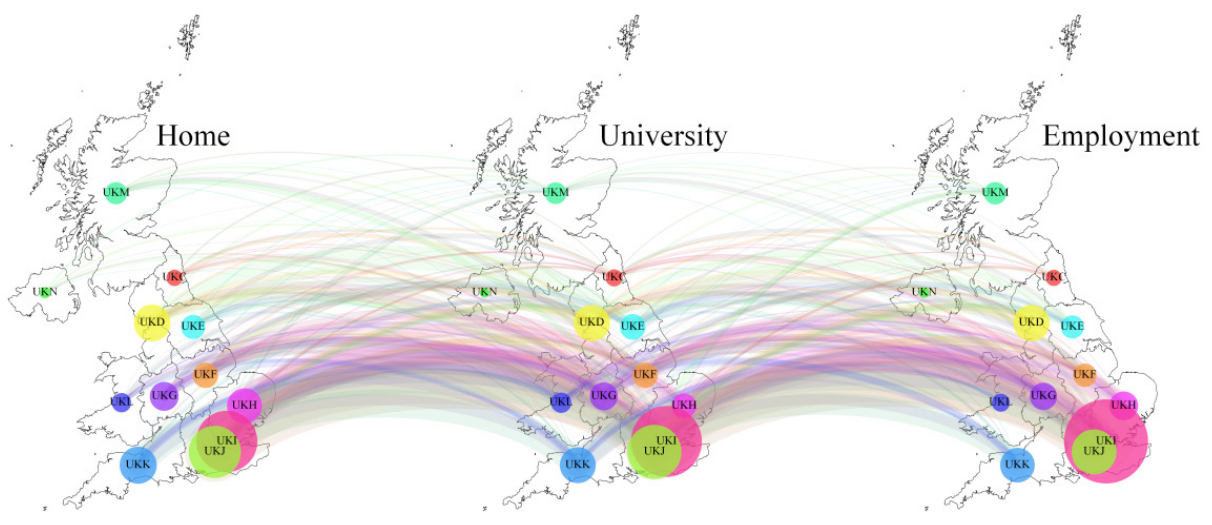

Source: data - HESA (2013), boundaries - EuroGeographics (2013).

Figure 1. Interregional mobility of entrepreneurial graduates between the UK's NUTS 1 regions

Table 2. Probability of choice between the regional units

\begin{tabular}{|c|c|c|c|c|c|c|}
\hline & & \multicolumn{5}{|c|}{ Startup (Employment) } \\
\hline & & London & Other England & Wales & Scotland & Northern Ireland \\
\hline \multirow{4}{*}{ Home } & London & $84.4(82.6)$ & $14.8(16.7)$ & $0.3(0.3)$ & $0.4(0.4)$ & $0.0(0.0)$ \\
\cline { 2 - 7 } & Other England & $14.2(11.6)$ & $84.1(86.6)$ & $0.8(1.0)$ & $0.9(0.8)$ & $0.1(0.0)$ \\
\cline { 2 - 7 } & Wales & $7.6(4.8)$ & $15.7(17.5)$ & $75.7(77.2)$ & $0.7(0.5)$ & $0.3(0.0)$ \\
\cline { 2 - 7 } & Scotland & $5.8(3.9)$ & $6.5(7.0)$ & $0.1(0.2)$ & $87.3(88.8)$ & $0.4(0.2)$ \\
\cline { 2 - 7 } & Northern Ireland & $7.8(4.4)$ & $9.4(11.4)$ & $1.2(0.4)$ & $2.7(3.9)$ & $78.9(79.9)$ \\
\hline \multirow{4}{*}{ University } & London & $69.8(71.7)$ & $28.4(27.1)$ & $0.8(0.5)$ & $0.8(0.5)$ & $0.1(0.1)$ \\
\cline { 2 - 7 } & Other England & $15.7(13.7)$ & $81.1(83.4)$ & $1.5(1.3)$ & $1.4(1.1)$ & $0.4(0.6)$ \\
\cline { 2 - 7 } & Wales & $5.7(5.0)$ & $34.3(28.9)$ & $58.9(65.3)$ & $1.0(0.6)$ & $0.1(0.2)$ \\
\cline { 2 - 7 } & Scotland & $6.0(4.8)$ & $9.8(9.1)$ & $0.1(0.3)$ & $82.9(84.7)$ & $1.1(1.1)$ \\
\cline { 2 - 7 } & Northern Ireland & $1.7(2.6)$ & $4.6(4.9)$ & $0.0(0.1)$ & $0.0(1.0)$ & $93.7(91.4)$ \\
\hline
\end{tabular}

Note: All respondents are in brackets. Source: HESA (2013).

Table 3. Distribution of graduate entrepreneurs for home-university-startup paths

\begin{tabular}{|c|c|c|c|c|c|c|}
\hline \multicolumn{2}{|c|}{ Home to university } & \multicolumn{4}{|c|}{ University to startup (employment) } & $\begin{array}{c}\text { Path } \\
\text { probabilitv }\end{array}$ \\
\hline \multirow{2}{*}{ Staying } & \multirow{2}{*}{$8,120(53.7 \%)$} & Staying & $7,034(86.6 \%)$ & & & $46.5 \%$ \\
\hline & & Going & $1,086(13.4 \%)$ & & & $7.2 \%$ \\
\hline \multirow{3}{*}{ Going } & \multirow{3}{*}{$6,997(46.3 \%)$} & Staying & $1,669(23.9 \%)$ & & & $11.0 \%$ \\
\hline & & \multirow{2}{*}{ Going } & \multirow{2}{*}{$5,328(76.1 \%)$} & Returning & $4,036(75.8 \%)$ & $26.7 \%$ \\
\hline & & & & Going & $1,291(24.2 \%)$ & $8.5 \%$ \\
\hline
\end{tabular}

Note: Probability in brackets. Source: HESA (2013). 
Table 4. Parameters of home $(H)$ to university $(U)$ location choice models

\begin{tabular}{|c|c|c|c|c|}
\hline & \multirow[t]{2}{*}{ Poisson } & \multirow[t]{2}{*}{ NB } & \multicolumn{2}{|c|}{ ZINB } \\
\hline & & & Inflate & Count \\
\hline Population_H & $0.313(0.047)^{\star \star *}$ & $0.783(0.107)^{\star \star *}$ & $-0.261(0.804)$ & $0.655(0.106)^{\star * *}$ \\
\hline Distance_HU & $-0.200(0.001)^{* * *}$ & $-0.250(0.004)^{* * *}$ & $3.039(0.426)^{* * *}$ & $-0.226(0.005)^{\star * *}$ \\
\hline Students_U & $0.799(0.019)^{\star * *}$ & $1.149(0.042)^{* * *}$ & $-2.867(0.32)^{\star \star \star}$ & $0.912(0.046)^{\star \star \star}$ \\
\hline Activity_H & $-0.562(0.19)^{\star * *}$ & $-1.533(0.445)^{* * *}$ & $-0.760(3.022)$ & $-1.021(0.462)^{* *}$ \\
\hline Startups_H & $0.909(0.174)^{* * *}$ & $0.116(0.359)$ & $-4.822(2.365)^{\star *}$ & $-0.032(0.380)$ \\
\hline Density_H & $0.190(0.03)^{\star * *}$ & $0.423(0.072)^{\star \star *}$ & $0.090(0.466)$ & $0.333(0.078)^{\star * *}$ \\
\hline Unemployment_H & $-1.488(0.174)^{\star * \star}$ & $-2.417(0.401)^{* * *}$ & $3.869(2.706)$ & $-1.978(0.411)^{* * *}$ \\
\hline SIC_2 & $-0.920(0.218)^{\star \star \star}$ & $-0.775(0.302)^{\star \star}$ & $0.296(3.612)$ & $-0.650(0.308)^{\star \star}$ \\
\hline SIC_3 & $1.335(0.097)^{\star * *}$ & $1.324(0.151)^{* * *}$ & $0.467(1.222)$ & $1.339(0.158)^{* * *}$ \\
\hline SIC_4 & $-1.165(0.247)^{\star \star \star}$ & $-1.156(0.334)^{\star * *}$ & $4.165(2.477)^{*}$ & $-0.832(0.357)^{* *}$ \\
\hline SIC_5 & $-1.947(0.34)^{\star * \star}$ & $-2.048(0.422)^{\star \star \star}$ & $5.310(3.841)$ & $-1.647(0.462)^{\star \star \star}$ \\
\hline SIC_6 & $0.709(0.113)^{* * *}$ & $0.381(0.186)^{\star *}$ & $-0.136(1.163)$ & $0.365(0.195)^{*}$ \\
\hline SIC_7 & $1.693(0.097)^{\star \star *}$ & $1.543(0.156)^{\star \star *}$ & $-0.139(1.044)$ & $1.535(0.161)^{* * *}$ \\
\hline SIC_8 & $-0.215(0.126)^{*}$ & $-0.389(0.185)^{\star *}$ & $2.119(1.249)^{*}$ & $-0.229(0.204)$ \\
\hline SIC_9 & $0.752(0.105)^{\star \star *}$ & $0.671(0.162)^{\star \star *}$ & $-0.134(1.604)$ & $0.663(0.172)^{\star * *}$ \\
\hline SIC_10 & $2.709(0.09)^{\star * *}$ & $2.749(0.141)^{* * *}$ & $-1.018(1.265)$ & $2.689(0.147)^{\star \star *}$ \\
\hline SIC_11 & $0.423(0.119)^{* * *}$ & $0.528(0.183)^{* * *}$ & $1.522(1.656)$ & $0.605(0.193)^{* * *}$ \\
\hline SIC_12 & $0.218(0.126)^{*}$ & $0.174(0.193)$ & $1.249(2.102)$ & $0.261(0.210)$ \\
\hline SIC_13 & $2.710(0.096)^{\star * *}$ & $2.586(0.152)^{* * *}$ & $-1.848(1.057)^{*}$ & $2.460(0.157)^{\star \star \star}$ \\
\hline SIC_14 & $1.456(0.097)^{\star \star \star}$ & $1.379(0.152)^{\star \star *}$ & $-0.996(1.248)$ & $1.298(0.158)^{\star * *}$ \\
\hline SIC_15 & $0.653(0.126)^{\star * *}$ & $0.732(0.204)^{* * *}$ & $2.480(2.057)$ & $0.898(0.226)^{\star * *}$ \\
\hline SIC_16 & $2.561(0.09)^{\star \star *}$ & $2.417(0.142)^{\star \star \star}$ & $-1.045(1.184)$ & $2.349(0.147)^{\star \star \star}$ \\
\hline SIC_17 & $2.537(0.092)^{\star * * *}$ & $2.516(0.145)^{* * *}$ & $-1.887(1.118)^{*}$ & $2.395(0.149)^{\star * *}$ \\
\hline SIC_18 & $2.852(0.089)^{* * *}$ & $2.914(0.140)^{* * *}$ & $-1.205(1.179)$ & $2.826(0.145)^{* * *}$ \\
\hline SIC_19 & $1.054(0.100)^{\star * *}$ & $0.941(0.156)^{\star * *}$ & $0.493(1.151)$ & $0.962(0.163)^{\star \star *}$ \\
\hline SIC_20 & $-1.161(0.208)^{* * *}$ & $-1.292(0.28)^{\star \star \star}$ & 2.662 (2.489) & $-1.099(0.294)^{\star \star *}$ \\
\hline H_SICweight & $0.226(0.032)^{\star \star *}$ & $0.308(0.066)^{\star \star *}$ & $0.860(0.608)$ & $0.368(0.070)^{* * *}$ \\
\hline Log(theta) & & $2.385(0.143)^{\star \star *}$ & & $1.134(0.067)^{\star * *}$ \\
\hline Log-likelihood & -5839 & -4323 & & -4227 \\
\hline Vuong test & & & & 6.98 \\
\hline
\end{tabular}

Note: 2,880 observations, intercept included, standard errors in parentheses, statistically significant at ${ }^{* * *} 0.01,{ }^{* *} 0.05,{ }^{*} 0.1$. Source: research results.

often from urban regions, regions with a positive situation in the labour market, but surprisingly also from economies with less entrepreneurial populations.

The first stage of choice of location also exhibits specific inclinations towards one economic sector or another for future graduates' startup. Future graduates tend to reject implementing business ideas within the energy supply and transportation sectors, and prefer professional, R\&D, as well as the health sector. Business creation is further discouraged in mining, water supply, and household services. All other sectors except real-estate appear to be preferred. The last variable measures the influence of sector weighting in the home region, giving an opportunity to approach the potential role of inspiration in sector choice. As expected, we reveal a significant positive influence.
Graduates seem to be inspired by sectors that are strongly represented in the home region.

Similar proportions are found in the second location choice. The dependent variable consists of 1,256 zero observations (43.6\% of the full sample). An average flow is again five startups, but the standard deviation increases to 21 startups. The choice reflects how graduates decide the location of their new business after graduation. Two scale variables and one separation variable behaved according to our expectations. We observed the essential role of distance in the rejection of long-distance mobility, as well as the paths from regions with relatively small student populations. The flows between the large student populations of the place of origin and the large residing populations of the destination are prominent, giving strong preference to nearby regions. 
MISCELLANEA GEOGRAPHICA - REGIONAL STUDIES ON DEVELOPMENT

Vol. $19 \cdot$ No. $4 \cdot 2015 \cdot$ pp. 34-43 • ISSN: 2084-6118 • DOI: 10.1515/mgrsd-2015-0024

Table 5. Parameters of university (U) to employment (E) location choice models

\begin{tabular}{|c|c|c|c|c|}
\hline & \multirow[t]{2}{*}{ Poisson } & \multirow[t]{2}{*}{ NB } & \multicolumn{2}{|c|}{ ZINB } \\
\hline & & & Inflate & Count \\
\hline Students_U & $0.663(0.019)^{* * *}$ & $1.080(0.043)^{\star * *}$ & $-2.859(0.295)^{* * *}$ & $0.831(0.045)^{\star \star \star}$ \\
\hline Distance_UE & $-0.211(-0.001)^{\star * *}$ & $-0.259(0.004)^{* \star *}$ & $3.682(0.430)^{\star * \star}$ & $-0.228(0.004)^{\star \star \star *}$ \\
\hline Population_E & $0.262(0.048)^{* * *}$ & $0.634(0.108)^{* * *}$ & $0.919(0.721)$ & $0.484(0.103)^{\star \star \star *}$ \\
\hline Activity_E & $0.069(0.195)$ & $-0.096(0.452)$ & $-5.229(2.717)^{\star}$ & $0.375(0.440)$ \\
\hline Startups_E & $1.320(0.180)^{\star * *}$ & $0.522(0.368)$ & $-9.733(2.168)^{* * *}$ & $0.003(0.376)$ \\
\hline Density_E & $0.162(0.031)^{\star * *}$ & $0.326(0.074)^{* * *}$ & $0.648(0.394)$ & $0.251(0.072)^{\star \star \star}$ \\
\hline Unemployment_E & $-0.784(0.179)^{\star * \star}$ & $-1.249(0.408)^{* \star *}$ & $3.853(2.212)^{*}$ & $-0.686(0.393)^{*}$ \\
\hline SIC_2 & $-0.641(0.222)^{* * *}$ & $-0.583(0.304)^{*}$ & $-8.755(421.21)$ & $-0.469(0.297)$ \\
\hline SIC_3 & $1.319(0.098)^{* * *}$ & $1.259(0.151)^{\star \star \star}$ & $2.716(1.284)^{\star *}$ & $1.386(0.150)^{\star \star \star}$ \\
\hline SIC_4 & $-0.755(0.245)^{* * *}$ & $-0.897(0.337)^{* \star *}$ & $3.822(2.790)$ & $-0.606(0.337)^{*}$ \\
\hline SIC_5 & $-1.624(0.356)^{\star * *}$ & $-1.832(0.436)^{* \star *}$ & $5.606(3.668)$ & $-1.449(0.442)^{\star \star \star}$ \\
\hline SIC_6 & $0.455(0.113)^{\star \star *}$ & $0.232(0.186)$ & $2.308(1.262)^{*}$ & $0.377(0.186)^{\star *}$ \\
\hline SIC_7 & $1.555(0.097)^{\star * *}$ & $1.429(0.156)^{* * *}$ & $1.544(1.183)$ & $1.503(0.152)^{\star \star *}$ \\
\hline SIC_8 & $-0.280(0.126)^{\star \star}$ & $-0.359(0.182)^{\star *}$ & $3.130(1.386)^{\star *}$ & $-0.204(0.188)$ \\
\hline SIC_9 & $0.761(0.106)^{\star * *}$ & $0.682(0.162)^{* * *}$ & $3.188(1.327)^{\star *}$ & $0.853(0.163)^{\star \star \star}$ \\
\hline SIC_10 & $2.667(0.090)^{\star * *}$ & $2.557(0.142)^{\star * \star}$ & $1.223(1.297)$ & $2.598(0.138)^{\star \star \star}$ \\
\hline SIC_11 & $0.471(0.119)^{* * *}$ & $0.478(0.185)^{* * *}$ & $2.894(1.680)^{*}$ & $0.600(0.182)^{\star * *}$ \\
\hline SIC_12 & $0.343(0.126)^{* * *}$ & $0.248(0.194)$ & $2.044(2.373)$ & $0.348(0.201)^{*}$ \\
\hline SIC_13 & $2.531(0.096)^{\star * *}$ & $2.406(0.153)^{\star * *}$ & $-0.572(1.184)$ & $2.341(0.149)^{\star \star * *}$ \\
\hline SIC_14 & $1.344(0.098)^{* * *}$ & $1.212(0.154)^{\star \star *}$ & $1.770(1.223)$ & $1.286(0.150)^{* * *}$ \\
\hline SIC_15 & $0.875(0.125)^{\star * *}$ & $0.913(0.203)^{\star * *}$ & $3.575(1.956)^{*}$ & $1.085(0.211)^{\star \star *}$ \\
\hline SIC_16 & $2.493(0.091)^{\star * *}$ & $2.319(0.143)^{* * *}$ & $1.049(1.249)$ & $2.355(0.139)^{\star \star \star}$ \\
\hline SIC_17 & $2.429(0.092)^{\star * *}$ & $2.474(0.145)^{* * *}$ & $-1.016(1.232)$ & $2.387(0.141)^{\star \star \star}$ \\
\hline SIC_18 & $2.786(0.090)^{\star * *}$ & $2.699(0.141)^{\star * *}$ & $0.500(1.254)$ & $2.677(0.136)^{\star \star *}$ \\
\hline SIC_19 & $0.989(0.101)^{\star * \star}$ & $0.870(0.156)^{\star \star \star}$ & $1.932(1.284)$ & $0.955(0.154)^{\star * *}$ \\
\hline SIC_20 & $-0.956(0.208)^{* * *}$ & $-1.276(0.289)^{* * *}$ & $7.370(2.152)^{* * *}$ & $-0.809(0.300)^{* * *}$ \\
\hline E_SICweight & $0.372(0.032)^{\star \star \star}$ & $0.433(0.065)^{* \star *}$ & $0.783(0.535)$ & $0.470(0.066)^{\star \star \star *}$ \\
\hline Log(theta) & & $2.484(0.156)^{* * *}$ & & $1.296(0.071)^{* * *}$ \\
\hline Log-likelihood & -5446 & -4165 & & -4014 \\
\hline Vuong test & & & & 8.36 \\
\hline
\end{tabular}

Note: 2,880 observations, intercept included, standard errors in parentheses, statistically significant at ${ }^{* * *} 0.01,{ }^{* *} 0.05$, ${ }^{*} 0.1$. Source: research results.

Locating startups in regions with problematic situations in their labour markets appears to be rejected first. Graduates tend to prefer regions with high entrepreneurial activity and startup rates. Population density plays no role in this first stage, but flows are more frequent towards wealthy urban regions. Considering sector choice, more sectors are placed among those already rejected in the first stage: transportation is the same as before, but this time not energy supply, which is replaced by a list including manufacturing, construction, accommodation and food services, financial services, public administration, and household services. The non-zero frequencies are much lower for energy and water supply, and household services, and are higher in particularly for five sectors: arts, ICT, health, education, and R\&D. We observed similarities in the preferences, but differences in their order. Health and education climbed up the list of preferences to reach number three and four, sending the professional and R\&D activities down from number three to number five. Graduates prefer high-skill services with the anticipation of direct personal contact. The positive influence of sector weight for destination region points to the spatial clustering of similar businesses, as a result of the choice of startup location.

\section{Conclusions}

The HE institutions possess the ability to encourage graduate startup formation. Recognizing and actively using synergies with characteristics of the various economic environments that the students come from, and where the graduates leave for, may prove to be a powerful mechanism influencing regional development. The systematic review of the literature that was performed, 
uncovers a series of conditions that are supportive in deciding where to locate and begin an entrepreneurial career. Supportive personal links and face-to-face interactions are crucial when starting up a new business. A startup friendly environment, which can be represented in the form of various cultural attributes, is also strongly emphasized. However, knowledge remains the major source crucial to identifying actual entrepreneurial opportunities, and human capital the major source of absorptive capacity in learning, with the universities appearing to play a substantial role. Generating knowledge through innovations and inventions is connected with the academic, as well as R\&D environment. The labour market, as well as the existing concentrations of financial security and employment opportunities are additional elements of new entrepreneurship location. A city in itself offers an exceedingly attractive environment for fresh entrepreneurs.

Different parts of the UK apparently represent various regional contexts for creating and supporting graduate entrepreneurs. Linkages to England and London dominate the system of flows. Future graduate entrepreneurs tend to reject distant moves from their home region when deciding on the location of their university studies. More graduates emerge from large populations, and they typically prefer universities with large student populations.
Domicile regions missing the experience of frequent business startups, will more probably experience rejection by nascent entrepreneurs in terms of locating their future firms. Graduates are inspired by sectors strongly represented in their home region, and also tend to reject business ideas in energy supply and transportation. On the contrary, they prefer professional, $R \& D$, as well as the health sector. Startup locations in regions with problematic labour market situations tends to be rejected. Generally, graduates do prefer to locate within regions with high entrepreneurial activity and startup rates. When considering sector choice, many sectors are not preferred, including manufacturing, construction, accommodation and food services, financial services, public administration, and household services. Moreover, graduates tend to value networks of high-skill strongly , and at the same time direct, personal contacts. Their choice points to the spatial clustering of similar businesses, exploiting located comparative advantages.

Acknowledgements: The authors are grateful to the grant award APVV VV-0018-12 for funding the research upon which this article is based.

\section{References}

Acs, ZJ, Anselin, L \& Varga, A 2002, 'Patents and innovation counts as measures of regional production of new knowledge', Research Policy, vol. 31, no. 7, pp. 1069-1085.

Acs, ZJ, Audretsch, DB \& Lehmann, EE 2013, 'The knowledge spillover theory of entrepreneurship', Small Business Economics, vol. 41, no. 4, pp. 757-774.

Acs, ZJ, Braunerhjelm, P, Audretsch, DB \& Carlsson, B 2009, 'The knowledge spillover theory of entrepreneurship', Small Business Economics, vol. 32, no. 1, pp. 15-30.

Acs, ZJ \& Sanders, M 2012, 'Patents, knowledge spillovers and entrepreneurship', Small Business Economics, vol. 39, no. 4, pp. 801-817.

Aldridge, TT \& Audretsch, D 2011, 'The Bayh-Dole Act and scientist entrepreneurship', Research Policy, vol. 40, no. 8, pp. 1058-1067.

Anderson, S, Culkin, N, Penaluna, A \& Smith, K 2014, 'University and colleges role' in An education system fit for an entrepreneur. Fifth Report by the All-Party Parliamentary Group for Micro Businesses, pp. 57-80.

Anselin, L, Varga, A \& Acs, Z 1997, 'Local geographic spillovers between university research and high technology innovations', Journal of Urban Economics, vol. 42, no. 3, pp. 422-448.

Anselin, L, Varga, A \& Acs, Z 2000, 'Geographical spillovers and university research: A spatial econometric perspective', Growth and Change, vol. 31, no. 4, pp. 501-515.

Armington, C \& Acs, ZJ 2002, 'The determinants of regional variation in new firm formation', Regional Studies, vol. 36, no. 1 , pp. 33-45.

Arrow, K 1962, 'Economic welfare and the allocation of resources for invention' in The rate and direction of inventive activity, ed RR Nelson, Princeton, Princeton University Press, pp. 609-626.

Ashcroft, B, Love, JH \& Malloy, E 1991, 'New firm formation in the British counties with special reference to Scotland', Regional Studies, vol. 25, no. 5, pp. 395-409.

Åstebro, T, Bazzazian, N \& Braguinsky, S 2012, 'Startups by recent university graduates and their faculty: Implications for university entrepreneurship policy', Research Policy, vol. 41, no. 4, pp. 663-677.
Audretsch, DB 1995, 'Innovation, growth and survival', International Journal of Industrial Organization, vol. 13, no. 4, pp. 441-457.

Audretsch, DB, Aldridge, TT \& Sanders, M 2011, 'Social capital building and new business formation: A case study in Silicon Valley', International Small Business Journal, vol. 29,no. 2, pp. $152-169$.

Audretsch, DB \& Fritsch, M 1994, 'The geography of firm births in Germany', Regional Studies, vol. 28, no. 4, pp. 359365.

Audretsch, DB, Lehmann, EE \& Warning, S 2005, 'University spillovers and new firm location', Research Policy, vol. 34, no. 7, pp. 1113-1122.

Audretsch, DB \& Vivarelli, M 1996, 'Determinants of new firm startups in Italy', Empirica, vol. 23, no. 1, pp. 91-105.

Autant-Bernard, C, Fadairo, M \& Massard, N 2013, 'Knowledge diffusion and innovation policies within the European regions: Challenges based on recent empirical evidence', Research Policy, vol. 42, no. 1, pp. 196-210.

Baltzopoulos, A \& Broström, A 2013, 'Attractors of entrepreneurial activity: Universities, regions, and alumni entrepreneurs', Regional Studies, vol. 47, no. 6, pp. 934-949.

Bishop, P 2012, 'Knowledge, diversity and entrepreneurship: a spatial analysis of new firm formation in Great Britain', Entrepreneurship \& Regional Development, vol. 24, no. 7-8, pp. 641-660.

Bosma, N, Van Stel, A \& Suddle, K 2008, 'The geography of new firm formation: Evidence from independent start-ups and new subsidiaries in the Netherlands', International Entrepreneurship and Management Journal, vol. 4, no. 2, pp. $129-146$.

Bosma, N 2011, 'Entrepreneurship, Urbanization Economies and Productivity of European Regions', Handbook of research on entrepreneurship and regional development, Cheltenham: Edward Elgar, pp. 107-132.

Brixy, U \& Grotz, R 2007, 'Regional patterns and determinants of birth and survival of new firms in Western Germany', Entrepreneurship \& Regional Development, vol. 19, no. 4, pp. 293-312.

Broström, A 2013, 'Learning and bonding: what do entrepreneurs have to gain from higher education?', 35th DRUID Celebration Conference, June 1719, 2013, Barcelona. 
Brzozowska, A, Glinka, B \& Postuła, A 2014. 'Role of university in creating entrepreneurial Attitudes', Horyzonty Wychowania, vol. 13, no. 26, pp. 51-71.

Buenstorf, G \& Klepper, S 2010, 'Why does entry cluster geographically? Evidence from the US tire industry', Journal of Urban Economics, vol. 68, no. 2, pp. 103-114.

Van Burg, E, Romme, AGL, Gilsing, VA \& Reymen, IMMJ 2008, 'Creating university spin-offs: A science-based design perspective', Journal of Product Innovation Management, vol. 25, no. 2, pp. 114-128.

Burt, RS 1992, 'Structural holes: The social structure of competition', Cambridge: Harvard University Press.

Carlton, DW 1983, 'The location and employment choices of new firms: An econometric model with discrete and continuous endogenoud variables', The Review of Economics and Statistics, vol. 65, no. 3, pp. 440-449.

Colombelli, A, Quatraro, F, Torino, P \& Alberto, CC 2013, 'New firm formation and the properties of local knowledge bases: Evidence from Italian NUTS 3 regions', 35th DRUID Celebration Conference, June 1719, 2013, Barcelona.

Colombo, MG, D'Adda, D \& Piva, E 2010, 'The contribution of university research to the growth of academic start-ups: an empirical analysis', The Journal of Technology Transfer, vol. 35 , no. 1, pp. 113-140.

Cooke, P, Asheim, BT, Boschma, R, Martin, R, Schwartz, D \& Tödtling, F 2011, Handbook of regional innovation and growth, Edward Elgar Publishing.

Dahl, MS \& Sorenson, O 2009, 'The embedded entrepreneur', European Management Review, vol. 6, no. 3, pp. 172-181.

Dahl, MS \& Sorenson, O 2010, 'The social attachment to place', Social Forces, vol. 89, no. 2, pp. 633-658.

Danis, WM, De Clercq, D \& Petricevic, O 2011, 'Are social networks more important for new business activity in emerging than developed economies? An empirical extension', International Business Review, vol. 20, no. 4, pp. 394-408.

Davidsson, P \& Honig, B 2003, 'The role of social and human capital among nascent entrepreneurs', Journal of Business Venturing, vol. 18, no. 3, pp. 301-331.

Dawson, C, Henley, A \& Latreille, P 2012, 'Individual motives for choosing self-employment in the UK: Does region matter?', Regional Studies, vol. 48, no. 5, pp. 804-822.

D‘Este PD, Mahdi, S, Neely, A \& Rentocchini, F 2012, 'Inventors and entrepreneurs in academia: What types of skills and experience matter?', Technovation, vol. 32, no. 5, pp. 293303.

Egeln, J, Gottschalk, S \& Rammer, C 2004, 'Location decisions of spin-offs from public research institutions', Industry and Innovation, vol. 11, no. 3, pp. 207-223.

Faggian, A \& McCann, P 2006, 'Human capital flows and regional knowledge assets: a simultaneous equation approach', Oxford Economic Papers, vol. 58, no. 3, pp. 475-500.

Faggian, A \& McCann, P 2008, 'Human capital, graduate migration and innovation in British regions', Cambridge Journal of Economics, vol. 33, no. 2, pp. 317-333.

Faggian, A \& McCann, P 2009, 'Universities, agglomerations and graduate human capital mobility', Tijdschrift voor Economische en Sociale Geografie, vol. 100, no. 2, pp. 210-223.

Fotheringham, AS 1986, 'Modelling hierarchical destination choice', Environment and Planning A, vol. 18. no. 3, pp. 401-418.

Fritsch, M \& Aamoucke, R 2013, 'Regional public research, higher education, and innovative start-ups: an empirical investigation', Small Business Economics, vol. 41, no. 4, pp. 865-885.
Fritsch, M. \& Mueller, P 2007, 'The persistence of regional new business formation-activity over time-assessing the potential of policy promotion programs', Journal of Evolutionary Economics, vol. 17, no. 3, pp. 299-315.

Van Geenhuizen, M \& Soetanto, DP, 2012, 'Open innovation among university spin-off firms: What is in it for them, and what can cities do?', Innovation: The European Journal of Social Sciences, vol. 25, no. 2, pp. 191-207.

Giarratana, MS 2004, 'The birth of a new industry: entry by startups and the drivers of firm growth', Research Policy, vol. 33, no. 5, pp. 787-806.

Gibb, A, Haskins, G \& Robertson, I 2013, 'Leading the entrepreneurial university: Meeting the entrepreneurial development needs of higher education institutions' in Universities in Change, Innovation, Technology, and Knowledge Management, ed A Altmann, \& B Ebersberger, Springer Science + Business Media, pp. 945.

Glinka, B \& Thatchenkery, T 2013, 'A comparative study of perceptions towards entrepreneurship in India, Poland, and the USA', International Journal of Human Resources Development and Management, vol. 13, no. 23, pp. 119-135.

Goethner, M, Obschonka, M, Silbereisen, RK \& Cantner, U 2012, 'Scientists' transition to academic entrepreneurship: Economic and psychological determinants', Journal of Economic Psychology, vol. 33, no. 3, pp. 628-641.

Greve, A. \& Salaff, JW 2003, 'Social networks and entrepreneurship', Entrepreneurship Theory and Practice, vol. 28 , no. 1 , pp. 122.

Griliches, Z 1979, 'Issues in assessing the contribution of research and development to productivity growth', Bell Journal of Economics, vol. 10, no. 1, pp. 92-116.

Guerini, M, Bonaccorsi, A, Rossi-Lamastra, C \& Colombo, M 2012, 'The spatial range of university knowledge and the creation of knowledge intensive firms', DRUID 2012 Conference, June 1921, 2012, Copenhagen.

Harrison, RT \& Leitch CM 2005, 'Entrepreneurial learning: Researching the interface between learning and the entrepreneurial context', Entrepreneurship Theory and Practice, vol. 29, no. 4, pp. 351-371.

Heblich, S \& Slavtchev, V 2013, 'Parent universities and the location of academic startups', Small Business Economics, vol. 42, no. 1, pp. 115.

Higher Education Statistics Agency 2013. Destinations of Leavers Survey. Available from: <https://www.hesa.ac.uk/ stats-dlhe>.

Higher Education Statistics Agency 2013. Students in Higher Education. Available from: <https://www.hesa. ac.uk/index.php?option=com_pubs\&task=show_pub_ detail\&pubid $=1 \&$ Itemid $=286>$.

Hoare, A \& Corver, M 2010, 'The regional geography of new young graduate labour in the UK', Regional Studies, vol. 44, no. 4 , pp. 477-494.

Hsu, DH, Roberts, EB \& Eesley, CE 2007, 'Entrepreneurs from technology-based universities: Evidence from MIT', Research Policy, vol. 36, no. 5, pp. 768-788.

Jacobs, J 1969, The economy of cities, New York, Random House.

Jaffe, AB 1989, 'The real effects of academic research', American Economic Review, vol. 79, no. 5, pp. 957-970.

Jaffe, AB, Trajtenberg, M \& Henderson, R 1993, 'Geographic localization of knowledge spillovers as evidenced by patent citations', The Quarterly Journal of Economics, vol. 108, no. 3, pp. 577-598.

Johnes, J. \& Taylor, J 1989, 'The first destination of new graduates: comparison between universities', Applied Economics, vol. 21, no. 3, pp. 357-373. 
Johnes, G, Taylor, J \& Ferguson, G 1987, 'The employability of new graduates: a study of differences between UK universities', Applied Economics, vol. 19, no. 5, pp. 695-710.

Landry, R, Amara, N \& Rherrad, I 2006, 'Why are some university researchers more likely to create spin-offs than others? Evidence from Canadian universities', Research Policy, vol. 35. no. 10, pp. 1599-1615.

Lasch, F 2011, 'Beyond the concept of human and social capital: the impact of the regional environment on high-tech venturing', International Journal of Entrepreneurship and Small Business, vol. 14, no. 1, pp. 56-76.

Lawton Smith, H, Chapman, D, Wood, P, Barnes T \& Romeo, $S$ 2014, 'Entrepreneurial academics and regional innovation systems: the case of spin-offs from London's universities', Environment and Planning C: Government and Policy, vol. 32, no. 2, pp. 341-359.

Lee, IH, Hong, E \& Sun, L 2013, 'Regional knowledge production and entrepreneurial firm creation: Spatial dynamic analyses ', Journal of Business Research, vol. 66, no. 10, pp. 2106-2115.

Malecki, EJ 1997, 'The R\&D location decision of the firm and "creative" regions - a survey', Technovation, vol. 6 , no. 3 , pp. 205-222.

Michelacci, C \& Silva, O 2007, 'Why so many local entrepreneurs?', The Review of Economics and Statistics, vol. 89, no. 4, pp. 615-633.

Mueller, SL \& Thomas, AS 2001, 'Culture and entrepreneurial potential: A nine country study of locus of control and innovativeness', Journal of Business Venturing, vol. 16, no. 1 , pp. $51-75$.

Mueller, SL, Thomas, AS \& Jaeger, AM 2002, 'National entrepreneurial potential: The role of culture, economic development, and political history' in Advances in Comparative International Management, eds MA Hitt \& JLC Cheng, vol. 14, pp. 221-257.

Müller, K 2010, 'Academic spin-off's transfer speed Analyzing the time from leaving university to venture', Research Policy, vol. 39, no. 2, pp. 189-199.

Northern Ireland Statistics and Research Agency 2013. LGD Claimant Count Annual Averages. Available from: <http:// www.ninis2.nisra.gov.uk/public/Theme.aspx?themeNumber $=18 \&$ themeName $=$ Labour\%20Market $>$

Office for National Statistics 2013. Business Demography. Available from: <http://www.ons.gov.uk/ons/rel/bus-register/ business-demography/index.html>.

Office for National Statistics 2013. Mid-year Population Estimates. Available from: <http://www.ons.gov.uk/ons/publications/rereference-tables.html?edition=tcm\%3A77-319259>.

Office for National Statistics 2013. Nomis. Available from: $<$ https://www.nomisweb.co.uk/>.

O'Shea, RP, Chugh, H \& Allen, T 2008, 'Determinants and consequences of university spinoff activity: A conceptual framework', The Journal of Technology Transfer, vol. 33, no. 6, pp. 653-666.

Pickernell, D, Packham, G, Jones, P, Miller, C \& Thomas B 2011, 'Graduate entrepreneurs are different: They access more resources?', International Journal of Entrepreneurial Behaviour \& Research, vol. 17, no. 2, pp. 183-202.

Piróg, D 2014a, 'Destinations of geography graduates on the labour market in Poland and other countries', Geographia Polonica, vol. 87, no. 1, pp. 95-112.
Piróg, D 2014b. 'Do geography degree programmes facilitate a smooth transition to the job market? Reflections of working and job-seeking graduates in Poland', Journal of Geography in Higher Education, vol. 38, no. 2, pp. 155-174.

Plotnikova, M, Wadeson, N \& Ashcroft, B 2010, 'Extending shiftshare decomposition through cluster analysis: An application to new firm formation in British counties', Henley Business School, University of Reading.

Qian, H \& Acs, ZJ 2013, 'An absorptive capacity of knowledge spillover entrepreneurship', Small Business Economics, vol. 40, no. 2, pp. 185-199.

Romer, P 1990, 'Endogenous technological change', Journal of Political Economy, vol. 98, no. 5, pp. 71-102.

Rothaermel, FT, Agung, SD \& Jiang, L 2007, 'University entrepreneurship: A taxonomy of the literature', Industrial and Corporate Change, vol. 16, no. 4, pp. 691-791.

Seddighi, HR \& Theocharous, AL 2002, 'A model of tourism destination choice: A theoretical and empirical analysis', Tourism Management, vol. 23, no. 5, pp. 475-487.

Shane, S \& Venkataraman, S 2000, 'The promise of entrepreneurship as a field of research', Academy of management review, vol. 25, no. 1, pp. 217-226.

Soetanto, DP \& Van Geenhuizen, M 2010, 'Social capital through networks: The case of university spin-off firms in different stages', Tijdschrift voor Economische en Sociale Geografie, vol. 101 , no. 5, pp. 509-520.

Storey, DJ 1991, 'The birth of new firms - Does unemployment matter? A review of the evidence', Small Business Economics, vol. 3, no. 3, pp. 167-178.

Sutaria, V \& Hicks, DA 2004, 'New firm formation: Dynamics and determinants', The Annals of Regional Science, vol. 38, no. 2, pp. 241-262.

Taylor, J 1986, 'The employability of graduates: Differences between universities', Studies in Higher Education, vol. 11, no. 1, pp. 17-27.

Varga, A 2000, 'Local academic knowledge transfers and the concentration of economic activity', Journal of Regional Science, vol. 40, no. 2, pp. 289-309.

Vincett, PS 2010, 'The economic impacts of academic spin-off companies, and their implications for public policy', Research Policy, vol. 39, no. 6, pp. 736-747.

Wach, K 2015, 'Impact of Cultural and Social Norms on Entrepreneurship in the EU: Cross-Country Evidence based on GEM Survey Results', Zarządzanie w Kulturze, vol. 16, no. 1 , pp. 15-29.

Wagner, J \& Sternberg, R 2004, 'Start-up activities, individual characteristics, and the regional milieu: Lessons for entrepreneurship support policies from German micro data', The Annals of Regional Science, vol. 38, no. 2, pp. 219-240.

Woodward, D, Figueiredo, O \& Guimarães, P 2006, 'Beyond the Silicon Valley: University R\&D and high-technology location', Journal of Urban Economics, vol. 60, no. 1, pp.15-32.

Wright, M, Mosey, S \& Noke, H 2012, 'Academic entrepreneurship and economic competitiveness: rethinking the role of the entrepreneur', Economics of Innovation and New Technology, vol. 21, no. 56, pp. 429-444. 